\title{
Gene expression profile of collagen types, osteopontin in the tympanic membrane of patients with tympanosclerosis
}

\author{
Monika Sakowicz-Burkiewicz, A, C-F, Jerzy Kuczkowski2, B, E, Tomasz Przybyła ${ }^{1, B, C, E}$, Marzena Grdeń1, C, E, \\ Anna Starzyńska ${ }^{3, B, E}$, Tadeusz Pawełczyk ${ }^{1, A, E, F}$ \\ ${ }^{1}$ Department of Molecular Medicine, Medical University of Gdańsk, Poland \\ ${ }^{2}$ Department of Otolaryngology, Medical University of Gdańsk, Poland \\ ${ }^{3}$ Department of Orofacial and Dental Surgery, Medical University of Gdańsk, Poland \\ A - research concept and design; $\mathrm{B}$ - collection and/or assembly of data; C - data analysis and interpretation; \\ $D$ - writing the article; $E$ - critical revision of the article; $F$ - final approval of article
}

Address for correspondence

Monika Sakowicz-Burkiewicz

E-mail: ssak@gumed.edu.pl

\section{Funding sources}

This study was supported by the Polish National

Science Center grant no. NN403211839 to TP.

Conflict of interest

None declared

Received on January 18, 2016

Revised on June 16, 2016

Accepted on February 14, 2017

\begin{abstract}
Background. Tympanosclerosis is a pathological process involving the middle ear. The hallmark of this disease is the formation of calcium deposits. In the submucosal layer, as well as in the right layer of the tympanic membrane, the calcium deposits result in a significant increase in the activity of fibroblasts and deposition of collagen fibers.

Objectives. The aim of our study was to examine the expression level of genes encoding collagen type I, I, III and IV (COLIA1, COL2A1, COL3A1, COL4A1) and osteopontin (SPP1) in the tympanic membrane of patients with tympanosclerosis.

Material and methods. The total RNA was isolated from middle ear tissues with tympanosclerosis, received from 25 patients and from 19 normal tympanic membranes. The gene expression level was determined by real-time RT-PCR. The gene expression levels were correlated with clinical Tos classification of tympanosclerosis.

Results. We observed that in the tympanic membrane of patients with tympanosclerosis, the expression of type I collagen is decreased, while the expression of type II and IV collagen and osteopontin is increased. Moreover, mRNA levels of the investigated genes strongly correlated with the clinical stages of tympanosclerosis.

Conclusions. The strong correlations between the expression of type I, II, IV collagen and osteopontin and the clinical stage of tympanosclerosis indicate the involvement of these proteins in excessive fibrosis and pathological remodeling of the tympanic membrane. In the future, a treatment aiming to modulate these gene expressions and/or regulation of the degradation of their protein products could be used as a new medical approach for patients with tympanosclerosis.
\end{abstract}

Key words: osteopontin, tympanosclerosis, collagen types

DOI

10.17219/acem/68984

Copyright

Copyright by Author(s)

This is an article distributed under the terms of the

Creative Commons Attribution Non-Commercial License

(http://creativecommons.org/licenses/by-nc-nd/4.0/) 
Tympanosclerosis is a chronic disease of the tympanic membrane and middle ear manifested by the accumulation of collagen in the elastic and fibrous layer of the lamina propria of the tympanic membrane, submucosal membrane of the tympanic cavity, auditory ossicles and mastoid cavity. The disease process most often refers to the eardrum. ${ }^{1}$ Tympanosclerosis limited to the tympanic membrane is called myringosclerosis and occurs in $24-82 \%$ of patients with tympanosclerotic lesions. ${ }^{1,2}$ The initiation of the immune response leads to the formation of deposits of hyaline with subsequent calcification and sometimes ossification of tympanosclerotic foci. ${ }^{3,4}$ These changes often lead to restricted mobility of the eardrum and ossicles, resulting in hearing loss. The tympanosclerotic plates formed from deposits of calcium, collagen fibers and hyaline masses result in conductive and mixed hearing impairment, by reducing the mobility of hearing elements, or in rare cases through the perforation of the eardrum, which exacerbates the hearing loss. Tympanosclerosis is characterized by dynamic ischemia and stiffening, and even the disappearance of the middle ear tissue. ${ }^{1,5}$

The etiology of tympanosclerosis is still not fully understood. A widely-accepted consensus recognizes the tympanosclerotic changes as a complication of acute inflammation or injury within the middle ear. ${ }^{2,6-10}$ A special role is attributed to otitis media with effusion, particularly if patient treatment involved the insertion of a catheter vent. ${ }^{11,12}$ Other factors that are taken into account in the etiology of tympanosclerosis include immunological processes, genetic predispositions, hypertension and hypercalcemia. ${ }^{13-16}$

Under the influence of cytokines and other regulatory factors, the fibrosis is initiated in the lamina propria of the tympanic membrane, involving degradation and vacuolization of fibrocytes. This results in the disintegration of cells and accumulation of deposits in the spaces between the collagen fibers. Endoplasmic reticulum released from the destroyed cells is equipped with calcium-binding receptors. This leads to an accumulation of calcium deposits and eventual calcification of tympanosclerotic foci. ${ }^{17}$ The activated immune cells as well as activated fibroblasts promote tissue remodeling. Our previous in vitro study on fibroblasts isolated from tympanosclerotic lesions demonstrated an up-regulated sensitivity of these cells to mast cell stimulation, which could significantly contribute to the ongoing fibrosis and pathological remodeling of the tympanic membrane. ${ }^{18}$

Our present study aimed to evaluate the expression level of genes encoding type I, II, III and IV collagen, and osteopontin in the tympanic membrane of patients with tympanosclerosis. Moreover, we determined the correlations between the gene expression levels and clinical stages of tympanosclerosis.

\section{Material and methods}

\section{Material}

Tympanic membranes were obtained from 25 patients with tympanosclerosis who underwent tympanoplasty in the local Department of Otolaryngology of the Medical University. Patients with accompanied inflammatory disease, with immune deficiency or those taking antibiotics or glucocorticosteroids within the last two weeks were excluded. The clinical stage of the tympanosclerotic lesion was assigned based on the intraoperative evaluation of tympanosclerotic changes according to a modified Tos classification as described previously. ${ }^{19}$ Morphologically normal tympanic membranes were dissected from 19 people who had died suddenly. The institutional review board at the Medical University previously approved all procedures (NKEBN/432/2009), and written consent was obtained from all patients. Immediately after resection, tissues were placed in RNAlater stabilization solution (Thermo Fisher Scientific, Walther, Massachusetts, USA) and stored at $-20^{\circ} \mathrm{C}$ until the isolation of RNA.

\section{Isolation of total RNA}

Isolation of total RNA was carried out in accordance with the Chomczyński procedure, with our own modifications. ${ }^{20}$ A TRI reagent and suspended material were vortexed briefly and then left standing for $10 \mathrm{~min}$ at $4^{\circ} \mathrm{C}$. Next, chloroform $(250 \mu \mathrm{L})$ was added, and the samples were vigorously shaken, incubated at $4^{\circ} \mathrm{C}$ for $15 \mathrm{~min}$ and centrifuged $\left(10,000 \times \mathrm{g}\right.$ for $15 \mathrm{~min}$ at $\left.4^{\circ} \mathrm{C}\right)$. The upper aqueous phase was removed into a new Eppendorf tube, an equal volume of isopropanol was added and RNA was precipitated by overnight incubation at $-20^{\circ} \mathrm{C}$, followed by centrifugation $\left(10,000 \times\right.$ g for $15 \mathrm{~min}$ at $\left.4^{\circ} \mathrm{C}\right)$. RNA pellets were washed first with $96 \%$ and then with $70 \%$ (v/v) ethanol, air-dried and resolved in diethyl-pyrocarbonatetreated thermo-sterilized water, and stored at $-20^{\circ} \mathrm{C}$ until further analysis.

\section{mRNA level determination}

The gene expression level was determined by real-time PCR performed in a Light Cycler 480 II (Roche Diagnostic GmbH, Manhein, Germany) using Path-IDTM Multiplex One-Step RT-PCR Kit and appropriate Universal ProbeLibrary Set, Human (Roche Applied Science). Transcript levels were normalized to that of the $\beta$-actin gene $(A C T B)$. The primer sequences, TaqMan probes and cycling conditions used are listed in Table 1.

\section{Statistical analysis}

Statistical analysis was performed using STATISTICA v. 12.0 (StatSoft, Inc., Tulsa, USA). The level of gene expres- 
Table 1. Primers and TaqMan probes and cycling conditions used for RT-PCR

\begin{tabular}{|c|c|c|}
\hline $\begin{array}{l}\text { Gene } \\
\text { transcript }\end{array}$ & Primers & TaqMan probe \\
\hline COLIA1 & $\begin{array}{l}\text { (F) gggattccctggacctaaag } \\
\text { (R) ggaacacctcgctctcca }\end{array}$ & $\begin{array}{c}\text { Universal ProbeLibrary } \\
\text { Probe \# } 67 \text { (Roche) }\end{array}$ \\
\hline $\mathrm{COL} 2 \mathrm{Al}$ & $\begin{array}{l}\text { (F) tggtgctaatggcgagaag } \\
\text { (R) cccagtctctccacgttcac }\end{array}$ & $\begin{array}{c}\text { Universal ProbeLibrary } \\
\text { Probe \# } 4 \text { (Roche) }\end{array}$ \\
\hline COL3A1 & $\begin{array}{l}\text { (F) agctggaaagagtggtgacag } \\
\text { (R) ccttgaggaccaggagcac }\end{array}$ & $\begin{array}{c}\text { Universal ProbeLibrary } \\
\text { Probe \# } 18 \text { (Roche) }\end{array}$ \\
\hline $\mathrm{CO} L 4 \mathrm{Al}$ & $\begin{array}{l}\text { (F) tggtgacaaaggacaagcag } \\
\text { (R) ggttcaccctttggacctg }\end{array}$ & $\begin{array}{c}\text { Universal ProbeLibrary } \\
\text { Probe \# } 81 \text { (Roche) }\end{array}$ \\
\hline SPP1 & $\begin{array}{l}\text { (F) cccacagacccttccaagta } \\
\text { (R) acactatcacctcggccatc }\end{array}$ & $\begin{array}{c}\text { Universal ProbeLibrary } \\
\text { Probe \# } 18 \text { (Roche) }\end{array}$ \\
\hline$A C T B$ & $\begin{array}{l}\text { Universal ProbeLibrary } \\
\text { Reference Gene Assay Roche, } \\
\text { Human ACTB Gene Assay }\end{array}$ & $\begin{array}{c}\text { Universal ProbeLibrary } \\
\text { Reference Gene Assay } \\
\text { Roche, Human ACTB } \\
\text { Gene Assay }\end{array}$ \\
\hline
\end{tabular}

Reverse transcription: $48^{\circ} \mathrm{C}$ (10 min), $95^{\circ} \mathrm{C}$ (10 min).

Amplification: $95^{\circ} \mathrm{C}(10 \mathrm{~s}), 60^{\circ} \mathrm{C}(45 \mathrm{~s})$.

sion in a normal tympanic membrane (control) and the tympanosclerotic samples were analyzed with a nonparametric Mann-Whitney U test. The correlations between the level of gene expression and clinical classification of tympanosclerosis were analyzed using Spearman's R ratio.

\section{Results}

To evaluate the contribution of collagens and osteopontin to the pathogenesis of sclerotic changes in the tympanic membrane, we determined the gene expression profile of COL1A1, COL2A1, COL3A1, COL4A1 and SPP1 in the tympanic membrane of patients with tympanosclerosis. The performed real-time PCR analysis showed the presence of COL1A1,COL2A1,COL3A1,COL4A1 and SPP1 in normal and sclerotic tympanic membranes, but the level of COL2A1 mRNA was barely detectable in the normal tympanic membrane. The level of gene profile expression of the collagen types and osteopontin in the selected structures of the middle ear with tympanosclerosis differed significantly compared to the healthy tympanic membranes (control group) (Fig. 1). We observed that the level of $C O L 1 A 1$ transcript was significantly decreased in tympanic membrane subjects with tympanosclerosis (Fig. 1A), whereas the expression level of $C O L 2 A 1$ was higher in sclerotic lesions of the tympanic membrane (Fig. 1B). The transcript levels of COL3A1 and $C O L 4 A 1$ were not altered in sclerotic tympanic membranes compared to controls (Fig. 1C, D). The expression level of the osteopontin gene (SPP1) was 7-fold higher in tympanosclerotic membranes compared to that determined in normal tympanic membranes (Fig. 1E).

Moreover, we compared the mRNA levels of the investigated genes within the patient groups arranged on the basis of Tos clinical classification of tympanosclerosis with our own modification. Our modification of the Tos classification concerns the study group division into 2 (instead of 3), i.e. group I - myringosclerosis with/or without perforation; group II - tympanosclerosis with/ or without perforation. We observed a much lower mRNA level of the COL1A1 gene in patients with stage II of tympanosclerosis. Expression of the COL1A1 gene was inversely correlated with the degree of tympanosclerotic changes (Spearman's rank correlation $(R)=-0.82$, $\mathrm{p}<0.05$, Fig. 2A). Moreover, increased expression of $\mathrm{CO}-$ $L 2 A 1$, and SPP1 genes strictly correlated with the severity of the disease $(\mathrm{R}=0.8$ and $\mathrm{R}=0.82, \mathrm{p}<0.05$, respectively, Fig. $2 \mathrm{C}, \mathrm{D})$. Interestingly, the mRNA level of the COL $4 A 1$ gene, which was not different in the study group compared to the control group, was correlated with the degree of tympanosclerotic changes $(\mathrm{R}=0.48, \mathrm{p}<0.05$, Fig. 2B).

\section{Discussion}

Tympanosclerosis (TS) is a chronic disease that is encountered at any age, but usually occurs in the years $30-50$. However, as many as $87 \%$ of patients are over 40 years old. ${ }^{21,22}$ The pathogenesis of TS is not clear. It usually develops following middle ear infection during the resolution phase of chronic otitis media. The clinical observations indicate that there are some differences in the disease procession between old and young patients. Tympanosclerosis in children is associated with secretory otitis media and the lesions are mostly limited to the tympanic membrane, whereas the tympanosclerotic changes in the elderly are also observed in other middle ear sites: the ossicular chain or the mastoid cavity. These changes are often accompanied by perforation of the tympanic membrane, varying degrees of destruction of the ossicles and accompanied diseases, such as hypercalcemia, hyperlipidemia or hypertension and atherosclerosis. ${ }^{1,9}$ The risk of TS especially increases in children who had ventilation tubes inserted. ${ }^{12,23}$ The clinical observations indicate that the frequency of myringosclerosis is much higher in tympanic membranes with tympanostomy tube insertion than in tympanic membranes with no tympanostomy tube insertion $(23-70 \%$ and $0-13 \%$, respectively). ${ }^{5,11,23-30}$ It was also observed that the myringosclerosis rate increased with a larger size of tube, several tube insertions and time of tympanostomy tube stay. ${ }^{25,29,31,32}$ Based on computer modeling, it has been shown that ventilation tube insertion induces shear stress in the structure of the tympanic membrane. The areas of maximal shear stresses have been found in the same positions as tympanosclerosis. It has been proposed that such stresses could damage the fibrils that connect the fibrous layer of the lamina propria and lead to TS. ${ }^{33}$ Furthermore, hyperoxic conditions, for- 
Fig. 1. Altered expression of genes (COLIAT, COL2A1, COL3A1, COL4A1) encoding collagens: type I (A), type II (B), type III (C), type IV (D), and gene (SSP-1) encoding osteopontin (E) in sclerotic lesion of tympanic membranes (TTM) and normal tympanic membranes (NTM). The data is means from at least 3 independent measurements performed on isolated total RNA from tympanic membranes, ${ }^{*} \mathrm{p}<0.0007 ;{ }^{* *} \mathrm{p}<0.002 ;{ }^{* * *} \mathrm{p}<0.00004$.

A

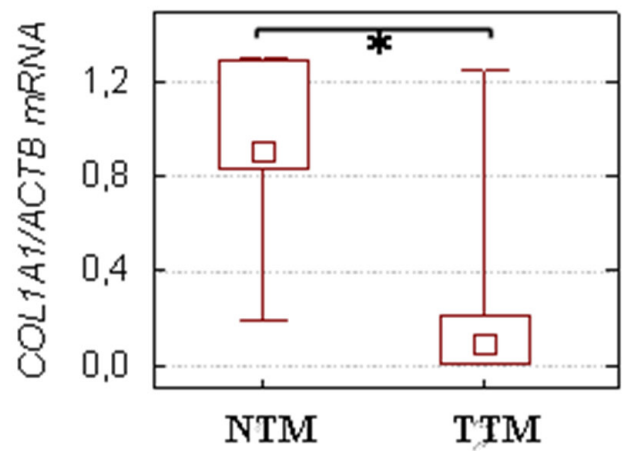

C

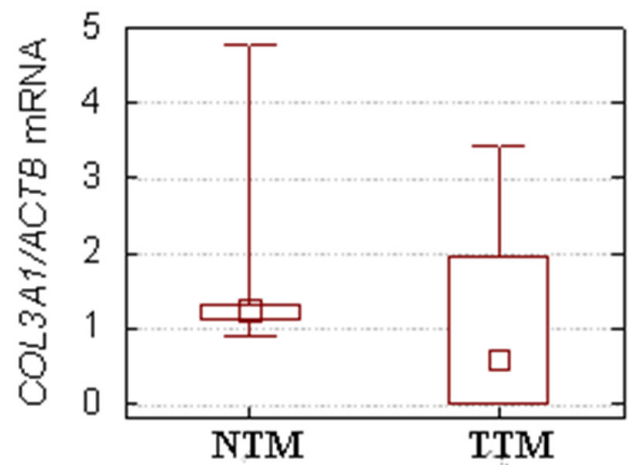

$\mathrm{E}$

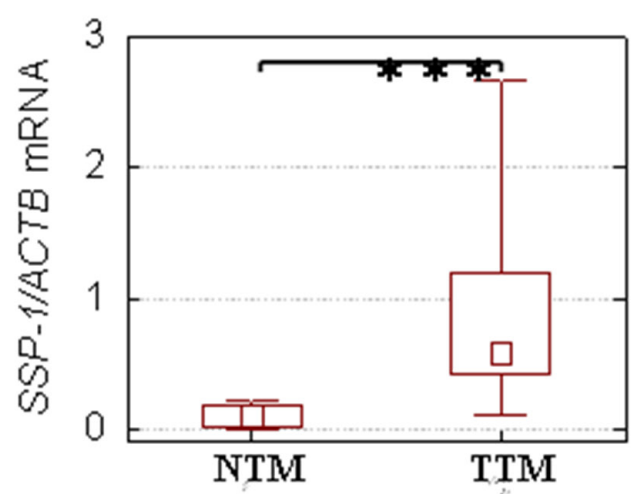

$\mathrm{B}$

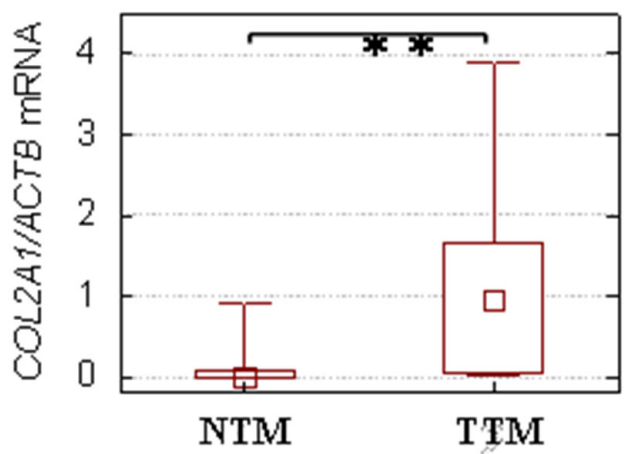

D

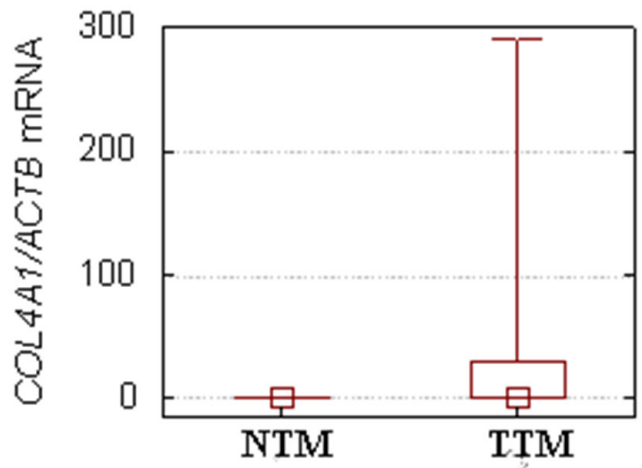

eign body reaction, inflammation, fibrous hyperplasia, hemorrhage and the release of free hemoglobin between the layers of the tympanic membrane are considered as factors involved in the development of myringosclerosis following tympanostomy tube insertion. ${ }^{25,29,34}$

Typically, tympanosclerotic changes proceed via the destruction of connective tissue followed by fibrosis resulting in elevated deposition of collagens and subsequent calcification of tissues in the middle ear. A recent histological study demonstrated that a healthy human tympanic membrane consists of collagen type I, II, III and IV. ${ }^{35}$ All these collagen types have different mechanical properties. The type I collagen fibers are resistant to force, and type II fibers are resistant to deformation. The type III collagen fibers are flexible and elastic, whereas type IV collagen provides support and transport. ${ }^{36}$

Earlier studies showed that an autoimmune reaction (both cellular and humoral) to type II collagen, an essential component of ear tissue, leads to, among other things, 
Fig. 2. Relation of the tympanosclerotic stage and the expression level of genes (COL1A1, COL2A1, COL4A1) encoding collagens: type I (A), type II (C), type IV (B), and gene (SSP-1) encoding osteopontin (D). The data is means from at least 3 independent determinations performed on isolated total RNA from tympanic membranes, ${ }^{*} p<0.0007 ;{ }^{* *} p<0.0002 ;{ }^{* * *} p<0.02 ;{ }^{* * *} p<0.05$.

A

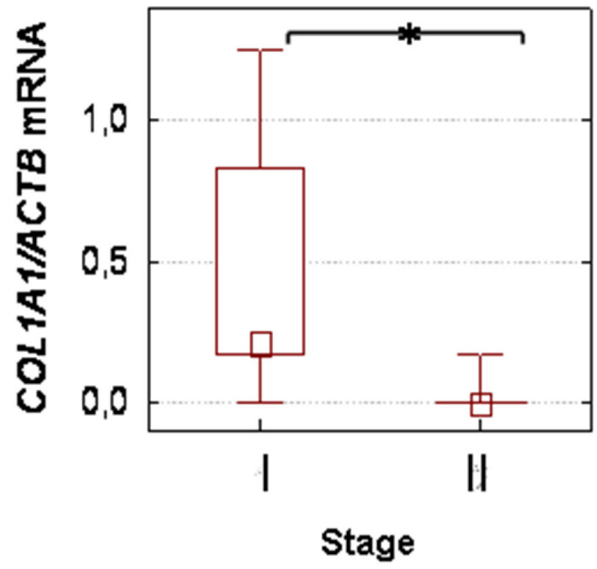

C

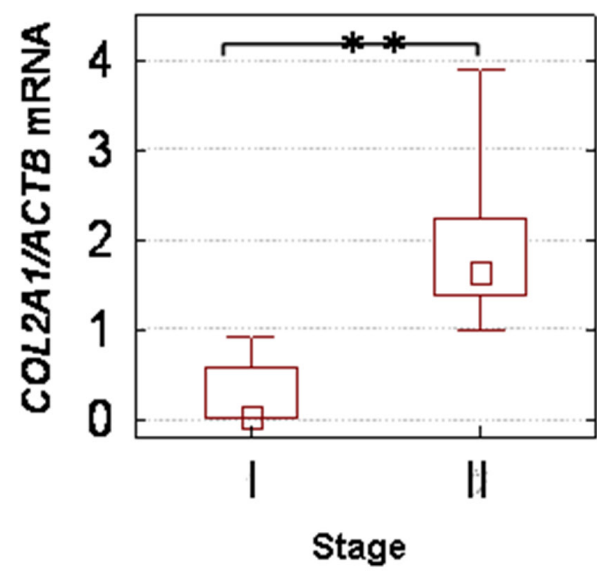

sensorineural hearing loss, vestibular dysfunction, endolymphatic hydrops, Eustachian tube inflammation and otitis media with effusion (not infectious). The tympanosclerotic membrane also has C3 and Ig deposits, which may suggest that tympanosclerosis is also induced by type II collagen immunization, especially in patients undergoing surgical incision of the tympanic membrane. ${ }^{37,38}$ The mechanisms of type II collagen autoimmune-mediated middle ear disease are not clear. In our study we observed that a normal tympanic membrane exhibits a very low level of COL $2 A 1 \mathrm{mRNA}$, which tremendously increased (4.9-fold) in tympanosclerotic foci.

Our study has not shown any significant changes in COL4A1 expression in the whole group of tympanosclerotic lesions, but we did observe an increase in type IV collagen expression in a subgroup of patients with stage II of tympanosclerosis compared to patients with stage I. This might indicate that the expression of COL4A1 increases with the propagation of the disease.
$\mathrm{B}$

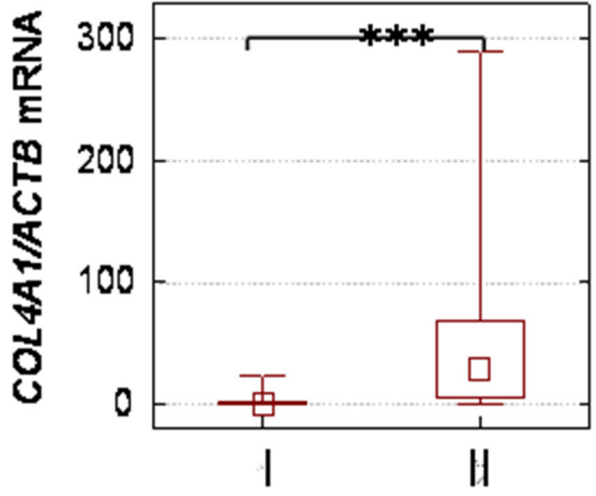

Stage

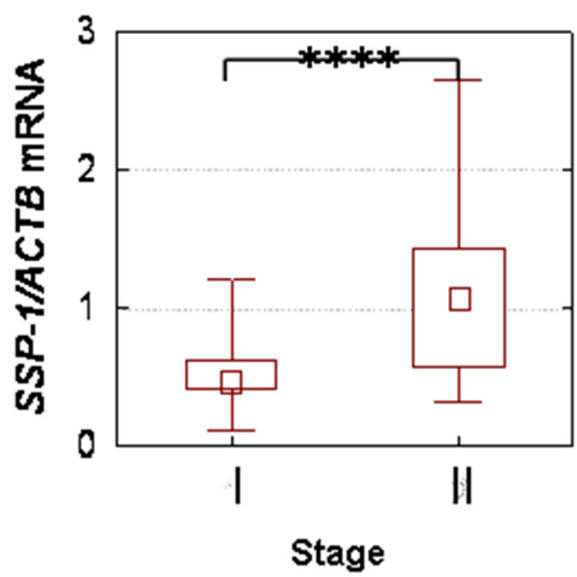

Osteopontin (OPN), also known as bone sialoprotein I, is a universal regulator of inflammation, biomineralization and tissue remodeling. Osteopontin is expressed by a variety of cell types including fibroblasts, osteoblasts, osteocytes, odontoblasts, hypertrophic chondrocytes, dendritic cells and macrophages. The elevation of OPN level accompanies the exposure of cells to pro-inflammatory cytokines (e.g. TNF $\alpha$, IL-1 $\beta$, TGF $\beta$ ). Several studies indicate that OPN is also up-regulated at sites of pathologic, ectopic calcification. ${ }^{29}$ A study by MakiishiShimobayashi et al. suggested that macrophage-derived increased expression of SPP1 in inflammatory tissues of the middle ear is involved in the development of tympanosclerosis. ${ }^{40}$ Our present study showed that the expression of SPP1 is significantly higher in tympanosclerotic foci and positively correlated with the degree of tympanosclerosis changes. Therefore, the manipulation of local OPN levels may be useful in the treatment of tympanosclerosis. 


\section{Conclusions}

Tympanosclerosis is a result of post-inflammatory fibrosis characterized by elevated deposition of collagens, and calcification. The present study, with a detailed analysis of the expression of collagen types and osteopontin during the tympanosclerotic process, shows that in the tympanosclerotic membrane the expression of type I collagen is decreased, and the expression of type II and IV collagen and osteopontin is increased.

The altered secretory phenotype of cells from the middle ear induces histological remodeling of the tympanic membrane and correlates with the progression of tympanosclerosis.

\section{References}

1. Asiri S, Hasham A, al Anazy F, Zakzouk S, Banjar A. Tympanosclerosis: review of literature and incidence among patients with middleear infection. J Laryngol Otol. 1999;113:1076-80.

2. Sheehy JL, House WF. Tympanosclerosis. Arch Otolaryngol. 1962;76:151-157.

3. Horowitz S. Heterotopic ossification in the middle ear. J Laryng Otol. 1952;66:181-186.

4. Tukaj C, Kuczkowski J, Sakowicz-Burkiewicz M, et al. Morphological alterations in the tympanic membrane affected by tympanosclerosis: Ultrastructural study. Ultrastruct Pathol. 2014;38:69-73.

5. Skarżyński H. Zalecany standard postępowania w operacjach poprawiających słuch w tympanosklerozie (stadium literaturowe, doświadczenia praktyczne). http://ifps.org.pl/doc/material_dydaktyka/skarzynski4.pdf. (read on 9 Nov. 2015)

6. Harris I. Tympanosclerosis - a revived clinicopathologic entity. The Laryngoscope. 1961;71:1488-1533.

7. da Costa SS, Paparella MM, Schachern PA, Yoon TH, Kimberley BP. Temporal bone histopathology in chronically infected ears with intact and perforated tympanic membranes. Laryngoscope. 1992;102:1229-1236.

8. Chang I. Tympanosclerosis. Acta Otolaryngol. 1969;68:62-72.

9. Gibb AG, Pang YT. Current considerations in the etiology and diagnosis of tympanosclerosis. Eur Arch Otorhinolaryngol. 1994;251:439-451.

10. Tos M, Stangerup SE, Larsen P. Dynamics of eardrum changes following secretory otitis: A prospective study. Arch Otolaryngol Head Neck Surg. 1987;113:380-385.

11. Hassmann-Poznańska E, Goździewski A, Piszcz M, Skotnicka B. Long term sequelae of otitis media with effusion during childhood. Otolaryngol Pol. 2010;64:234-239.

12. Zielnik-Jurkiewicz B, Olszewska-Sosińska O, Rakowska M. Results of treatment with tympanostomy tubes in children with otitis media with effusion. Otolaryngol Pol. 2006;60:181-185.

13. Forséni M, Bagger-Sjöbäck D, Hultcrantz M. A study of inflammatory mediators in the human tympanosclerotic middle ear. Arch Otolaryngol Head Neck Surg. 2001;127:559-564.

14. Schiff M, Yoo TJ. Immunologic aspects of otologic disease: An overview. Laryngoscope. 1985;95:259-269.

15. Koc A, Uneri C. Genetic predisposition for tympansclerotic degeneration. Eur Arch Otorhinolaryngol. 2002;259:180-183.

16. de Carvalho Leal M, Ferreira Bento R, da Silva Caldas Neto $S$, et al. Influence of hypercalcemia in the formation of tympanosclerosis in rats. Otol Neurotol. 2006;27:27-32.

17. Tos M. Surgical solutions for conductive hearing loss. Stuttgart, New York: Thieme; 2000.

18. Pawelczyk T, Sakowicz-Burkiewicz M, Wesserling M, Grden M, Kuczkowski J. Altered response of fibroblasts from human tympanosclerotic membrane to interacting mast cells: Implication for tissue remodeling. Int J Biochem Cell Biol. 2014;57:35-44.
19. Mionskowski T, Kuczkowski J, Sakowicz-Burkiewicz M. Określenie profilu ekspresji genu TNFa w wybranych strukturach ucha środkowego u chorych na tympanosklerozę. Otolaryngol Pol. 2012;66:20-24

20. Chomczynski P, Sacchi N. Single-step method of RNA isolation by acid guanidinium thiocyanate-phenol-chloroform extraction. Anal Biochem. 1987;162:156-159.

21. Huang ZY, Zhou FH, Xie NP, Guo MH, Wan LC, Sun WQ. Clinical analysis of 11 patients with tympanosclerosis. Nan Fang Yi Ke Da Xue Xue Bao. 2010:30:345-348.

22. Kinney SE. Postinflammatory ossicular fixation in tympanoplasty. Laryngoscope. 1978;88:821-38.

23. Vlastarakos PV, Nikolopoulos TP, Korres S, Tavoulari E, Tzagaroulakis A, Ferekidis E. Grommets in otitis media with effusion: The most frequent operation in children. But is it associated with significant complications? Eur J Pediatr. 2007;166:385-391.

24. Slack RW, Maw AR, Capper JW, Kelly S. Prospective study of tympanosclerosis developing after grommet insertion. J Laryngol Otol. 1984:98:771-774.

25. Yaman H, Yilmaz S, Alkan N, Subasi B, Guclu E, Ozturk O. Shepard grommet tympanostomy tube complications in children with chronic otitis media with effusion. Eur Arch Otorhinolaryngol. 2010;267:1221-1224.

26. Kay DJ, Nelson M, Rosenfeld RM. Meta-analysis of tympanostomy tube sequelae. Otolaryngol Head Neck Surg. 2001;124:374-80.

27. Cayé-Thomasen $P$, Stangerup $S E$, Jorgensen $G$, Drozdziewic D, Bonding $\mathrm{P}$, Tos $\mathrm{M}$. Myringotomy versus ventilation tubes in secretory otitis media: Eardrum pathology, hearing, and eustachian tube function 25 years after treatment. Otol Neurotol. 2008;29: 649-657.

28. Pereira MB, Pereira DR, Costa SS. Tympanostomy tube sequelae in children with otitis media with effusion: A three-year follow-up study. Braz J Otorhinolaryngol. 2005;71:415-420.

29. Yaman H, Guclu E, Yilmaz S, Ozturk O. Myringosclerosis after tympanostomy tube insertion: Relation with tube retention time and gender. Auris Nasus Larynx. 2010;37:676-679.

30. Tos M, Stangerup SE. Hearing loss in tympanosclerosis caused by grommets. Arch Otolaryngol Head Neck Surg. 1989;115:931-935.

31. Maw AR. Development of tympanosclerosis in children with otitis media with effusion and ventilation tubes. J Laryngol Otol. 1991;105:614-761.

32. Yaman H, Yilmaz S, Guclu E, Subasi B, Alkan N, Ozturk O. Otitis media with effusion: Recurrence after tympanostomy tube extrusion. Int J Pediatr Otorhinolaryngol. 2010;74:271-274.

33. Lesser TH, Williams KR, Skinner DW. Tympanosclerosis, grommets and shear stresses. Clin Otolaryngol Allied Sci. 1988;13:375-380.

34. Koc A, Uneri C. Sex distribution in children with tympanosclerosis after insertion of a tympanostomy tube. Eur Arch Otorhinolaryngol. 2001;258:16-19.

35. Knutsson J, Bagger-Sjöbäck D, von Unge M. Collagen type distribution in healthy human tympanic membrane. Otol Neurotol. 2009;30:1225-1229.

36. Gelse K, Pöschl E, Aigner T. Collagens-structure, function, and biosynthesis. Adv Drug Deliv Rev. 2003;55:1531-1546.

37. Yoo TJ, Sudo N, Tomoda K, et al. Type II collagen mediated autoimmune middle ear disease: Eustachian tube disease, otitis media with effusion and tympanosclerosis. Auris Nasus Larynx. 1985;12:S91-S93.

38. Yoo TJ, Floyd RA, Sudo N, et al. Factors influencing collageninduced autoimmune ear disease. Am J Otolaryngol. 1985;6: 209-216.

39. Cho HJ, Cho HJ, Kim HS. Osteopontin: A multifunctional protein at the crossroads of inflammation, atherosclerosis, and vascular calcification. Curr Atheroscler Rep. 2009;11:206-213.

40. Makiishi-Shimobayashi C, Tsujimura T, Sugihara A, et al. Expression of osteopontin by exudate macrophages in inflammatorytissues of the middle ear: A possible association with development of tympanosclerosis. Hearing Res. 2001:153:100-107. 